Cahiers $d u$ MONDE RUSSE

\section{Cahiers du monde russe}

Russie - Empire russe - Union soviétique et États indépendants

$61 / 3-4 \mid 2020$

Écritures visuelles, sonores et textuelles de la justice

\title{
Paul BUSHKOVITCH, ed., The State in Early Modern Russia New directions
}

\section{Alexander Filyushkin}

\section{OpenEdition}

\section{Journals}

Electronic version

URL: https://journals.openedition.org/monderusse/12066

DOI: $10.4000 /$ monderusse. 12066

ISSN: $1777-5388$

\section{Publisher}

Éditions de l'EHESS

\section{Printed version}

Date of publication: 1 July 2020

Number of pages: $501-504$

ISBN: 978-2-7132-2832-2

ISSN: $1252-6576$

Electronic reference

Alexander Filyushkin, "Paul BUSHKOVITCH, ed., The State in Early Modern Russia New directions",

Cahiers du monde russe [Online], 61/3-4 | 2020, Online since 01 July 2020, connection on 22 September 2022. URL: http://journals.openedition.org/monderusse/12066 ; DOI: https://doi.org/10.4000/ monderusse. 12066 
$\begin{array}{ccccccccccccccc}R & \text { U } & \text { S } & \text { S } & \text { I } & \text { E } & & \text { A } & \text { N } & \text { C } & \text { I } & \text { E } & \text { N } & \text { N } & \text { E } \\ & \text { E } & \text { T } & & \text { I } & M & \text { M } & \text { E } & \text { R } & \text { I } & \text { A } & \text { L } & \text { E } & & \end{array}$

Paul BUSHKOVITCH, ed.

\section{The State in Early Modern Russia New directions}

Bloomington, IN : Slavica Publishers, 2019, 348 p.

Re-examination of Russian history which began in 1991 often happens in reverse: the more recent the event, the more scrutiny it suffers. It is mainly focused on the history of the USSR. Deeper in the past it becomes less intensive. It shows little concern for the $18^{\text {th }}-19^{\text {th }}$ century history of the Russian Empire, and even less concern for the history of medieval Russia and Russia of Early New Time. It is not that few phenomena from the Russian history of the $9^{\text {th }}-17^{\text {th }}$ centuries are re-examined. On the contrary, there are many interpretations based on new sources introduced into scientific discourse. Today we have obtained new data about the circumstances of the Vikings' arrival in Russia ${ }^{1}$. We have examples of new views on the history of the Ancient Rus' 2 . Some scholars demonstrate fresh views upon the history of the Mongol-Tatar conquest ${ }^{3}$. New concepts of the genesis of the Moscow Rus ${ }^{\prime 4}$ statehood are proposed, etc.

However, these hypotheses and concepts are so diverse that they do not yet form a new panorama of the pre-Peter Russia. The choice of a research method remains an open issue. Today, various methods are used to reconstruct the past of Muscovite Russia hindering the process of forming conventional theories. Yet in order to decide what research methods have more potential, they need to be tested. The book under review edited by Paul Bushkovitch can serve as an example. Its very title represents an experimental approach, 'The State in Early Modern Russia: New directions.' The volume contains the results of discussions at a conference 'Rethinking Early Modern Russia' held at Yale University in April 2015.

The papers included in the collection can be classified as follows. A number of them offer a new perspective on the nature of the Muscovite state. Charles Halperin, in "The Nature of the Muscovite State During the Reign of Ivan the Terrible: The Tyranny of Concepts" (p. 77-96), considers various definitions of Muscovy, whether it was a European or Eurasian state, whether it could be called an empire, 'early modern state,' 'hypertrophic or consensual-collegial state,' 'a composite state,' 'a Renaissance state, ' 'a national state,' etc. He analyzes different historical categories traditionally attributed to Muscovy, mainly in the fields of social relations and political institutions. Halperin concludes that 'a combination of centralization and decentralization, of aristocracies, gentries and bureaucrats, put Muscovy in sync with many other contemporary states in their social programs and methods of governance' (p. 91).

In his paper "Duration of Integration as a Factor in Russian History and Its Impact on Social and Political Development in Sixteenth-century Russia" (p. 97-131), Nikolai Petrukhintsev discusses a connection between integration of 
territories, state-building and social policy. The author seeks to connect the features of social strategies of the elite, career scenarios, relocation of the nobility within state structures and institutions, etc. However, for some reason Petrukhintsev's hypotheses are based on outdated works. A.A. Zimin's papers on genealogy of the Russian nobility and its social history were very promising in the $1950 \mathrm{~s}$ and $60 \mathrm{~s}$, yet since then many books and articles have been published which clarified and revised many of Zimin's conclusions. It would be useful to consider Petrukhintsev's article in the context of modern historiography (see books of Tat' iana Pashkova's, Andrey Kuzmin's, Michael Bentsianov's, etc. $)^{5}$.

In his paper "The Tsar and the Sobor: Russia 1613-53" (p. 133-161), Paul Bushkovitch touches upon a frequently debated yet never resolved issue of the relationship between estates and political institutions in Muscovy (Zemskii sobor plays the role of the Assembly of the Land). According to the author, there remains a number of difficulties in studying the real role of the Assembly of the Land, still he concludes that "The Russian state before Peter was not an autocracy, it was a conglomerate of several elements": a monarch, a boyar oligarchy, an administrative apparatus and Assembly of the Land (p. 161).

Nancy Kollmann ("Frugal Empire: Sources of Russian state Power," p. 335-347) stresses that "Russia was a classic early modern Eurasian empire" (p. 335). She makes analogies with the Ottoman Empire. In the simplicity and underdevelopment of the administrative, judicial, and social structures of the Empire the author discovers an advantage - the "frugal" Empire preferred to rely on traditional social structures and adapt them to imperial conditions rather than to develop new ones. This allowed to achieve results with small funds, to build "empire on the cheap" (p. 344). This idea seems very important: it explains why Russia was able to build an Empire and meet comparatively little resistance to imperial construction. Hence the reasons why when faced with "costly," "expensive" European empires, Russia immediately had difficulties, especially in the case of a long-running conflict.

Another part of the volume consists of papers devoted to various forms of representation of power in early modern Russia. Michael Flier ("Branching Out: The Roots of Muscovite Dynastic Representation," p. 59-76) studies the origins of Moscow's political ideology. He puts them in the context of biblical and Orthodox discourses. The article examines the phenomenon of the Tree of Jesse, which, according to the author, formed the basis of family trees (dynastic and state). Using this genealogy, the continuity and the transition from Muscovite Rus' to Imperial Russia was declared (p. 76).

Ernest Zitser ("Multitemporality and the Politics of Time in the Age of Peter the Great: Rethinking Russia’s “Big Bang,” p. 269-304) presents one of the most innovative papers in this volume. He considers the concept of "modernity" in relation to Peter's Russia in the context of different views on temporality. Zitser analyzes these views on the example of the astrologically oriented narrative "Vita del Principe Boris Ivanovich Koribut-Kurakin de la familia de Polonia et Litoania" and demonstrates how the author's worldview manifested different ways and styles of perception of historical epochs in relation to modernity. This multitemporality, 
according to Zitser, reflects the temporal practices adopted at the court of Peter the Great (p. 301).

A number of papers devoted to various fields offer new methods of studying them. Petr Stefanovich ("Poliud'e and the Evolution of Taxation from Rus' to Russia”, p. 7-28) compares the famous phenomenon of polyud'e in Ancient Russia with the tax practices of the late middle ages in the Grand Duchy of Lithuania. Martin Russell ("Familial Order, Dynasty and Succession in Early Modern Russia: Toward a Gendered History of the Muscovite Dynasty," p. 29-58) draws attention to the fact that the Daniilovich dynasty was agnatic in its characteristics. This created a special system of gender relations in the upper strata of the Moscow aristocracy (historian suggests its scheme, p. 56). Olga Kosheleva ("Education as a Problem in Seventh-Century Russia," p. 191-218) identifies eight approaches to the study of the problem of the spread of education in 17th-century Russia and brilliantly criticizes their correlation with the historical realities of this century. Eve Levin ("The Aptekarskii Prikaz and the Limits of Western Influence", p. 219-248) evaluates the style and degree of westernization of Muscovy through the distribution of medical knowledge. Pavel Sedov ("The role of Tradition in the Success of the Reforms of Peter I," p. 249-268) shows connections between Peter's reforms and the traditions laid down by his predecessors. The conviction that these reforms were not "Big Bang" at all, but were in a number of ways a continuation of "long processes" of the 17th century, is getting more and more evidence during the last decades. Finally, two articles (Nadieszda Kizenko, "The Sacrament of Confession as Encounter with Early Modernity," p. 163-190; Olga Tsapina, "The 1721 Church Reform and the Constructing the Orthodox Tradition of Church-State Relations in Russia," p. 305-334) are devoted to various aspects of Church history in the context of political traditions and modernity.

The issue, edited by Paul Bushkovitch, provides a lot of new results, contains instructive examples of testing modern methods of studying history. It will give useful hints and directions for studying Muscovy.

1 - See the last review: V.Ia. Petrukhin, "Novgorodskoe gorodishche i Gnëzdovo: 40 let polemiki," Studia Slavica et Balcanica Petropolitana, 2 (2019): 93-100.

2 - A.P. Tolochko, Ocherki nachal'noi Rusi (Kiev - Sankt-Peterburg: Laurus, 2015); P.V. Lukin, Novgorodskoe veche (M.: Indrik, 2014, $1^{\text {st }}$ ed.; M.: Akademicheskii proekt, 2018, $2^{\text {nd }}$ ed.).

3 - For ex.: I. Vásáry, "The tatar factor in the formation of Muscovy’s political culture," in R. Amitai, M., Biran, eds., Nomads as Agents of Cultural Change: The Mongols and their Eurasian Predecessors (University of Hawaii Press, 2014), 252-270; N.N. Kradin, "Vostochnaia Evropa i mongol'skaia globalizatsiia," Stratum Plus, 5 (2016): 17-27; S.V. Tomsinskii, "Krizis Drevnei Rusi v XIII v.: vozmozhnosti poznaniia realii istoricheskoi deistvitel'nosti," Stratum Plus, 5 (2016): 27-38; etc.

4 - Last books: N. Kollmann, The Russian Empire 1450-1801 (Oxford University Press, 2017); D. Rowland, God, Tsar, and People: The Political Culture of Early Modern Russia (Northern Illinois University Press, 2020).

5 - T.I. Pashkova, Mestnoe upravlenie v russkom gosudarstve pervoi polovine XVI veka: namestniki i volosteli (M.: Drevnekhranilishche, 2000); A.V. Kuz'min, Na puti v Moskvu. Ocherki genealogii voenno-sluzhiloi znati Severo-Vostochnoi Rusi v XIII-seredine 
$X V$ v. (M.: Rukopisnye pamiatniki Drevnei Rusi, 2014-2015), t. 1, 2; M.M. Bentsianov, «Kniaz'ia, boiare $i$ deti boiarskie»: Sistema sluzhebnykh otnoshenii v Moskovskom gosudarstve $v X V-X V I v v$. (M.: Tsentroligraf, 2019); S.V. Chernikov, "K voprosu o"neukorenennosti" moskovskogo sluzhilogo klassa: izmeneniia $\mathrm{V}$ famil'nom sostave dvorianstva v uezdakh Evropeiskoi Rossii v XVII-nachale XVIII vv.," Cahiers du monde russe, 61, 1-2 (2020).

Alexander Filyushkin

St.-Petersburg State University, Russia 